\title{
Research on Blended Teaching Pattern of "online + offline" of Circuit Principle Course
}

\author{
Ruini Liu \\ College of engineering and technology, Xi'an Fanyi University, Xi'an 710105, China \\ 463736072@qq.com
}

Keywords: Circuit principle; "Online + offline"; Blended teaching; Teaching reform

\begin{abstract}
The rapid development of "Internet + " technology has greatly promoted the reform of education teaching mode. Based on the analysis of the problems in the course teaching and the characteristics of blended teaching pattern, this paper proposes the application of blended teaching pattern to solve these problems. In this paper, the blended teaching system of "online + offline" is constructed, and the comparison teaching experiment is conducted. The results show that the application of blended teaching mode can effectively improve the teaching quality of the circuit principle course.
\end{abstract}

\section{Introduction}

Circuit principle course is a very important professional basic course in electronic related major, which mainly to teach the basic principle of dc and ac circuits, circuit theorem and law, and the practical application of circuit. The content of the course is wide, informative, theoretical and practical. It is a course that students generally find difficult to learn and difficult to understand, and it is not easy to pass the exam [1]. As a first-line teacher who has been engaged in the course teaching of circuit principles for many years, I deeply appreciate the problems existing in traditional teaching[2]: (1) "more content, less class hours", this is the first challenge of circuit principle course. Many colleges have classes are compressed. How to improv the teaching quality and effectin the limited class hours?only to change our traditional teaching mode, looking for new situation of the new teaching mode. (2) "teacher as the center, it is difficult to exert students' initiative". Teacher is the center of the classroom in the traditional way of teaching. In this way, students learn what teacher teaching only, so the student main body status is not prominent, learning initiative is not high. It makes the teacher and student both tired. There is a lack of communication between teachers and students, and students can not be fully and effectively tutored. (3) "teaching content is out of step with life and engineering practice". The traditional teaching method emphasizes theoretical knowledge teaching, and weakens the practice and application teaching. A lot of students will do exercise, will test, and have theoretical knowledge, but do not know how to apply to life and engineering practice. They can not understand the depth and sense of accomplishment brought by the practice, and the advanced nature and practicability of the circuit curriculum.

Blended teaching pattern of "online + offline" has emerged with the development of "Internet +" technology, which is a teaching mode that combines multimedia teaching and network teaching with traditional teaching to realize complementary advantages[3]. Blended teaching focuses on optimizing achievement of learning objectives by applying the "right" learning technologies to match the "right" personal learning style to transfer the "right" skills to the "right" person at the "right" time[4]. Many documents show that blended teaching has become prevalent in the world [5-8]. With the development of information technology and Internet, the combination of face-to-face classroom teaching and online learning can achieve better teaching effect $[9,10]$. The emergence of blended teaching provides a new idea for the teaching reform of education. In this paper, the research and exploration of "online + offline" blended teaching mode is carried out based on the teaching situation of the circuit principle of our school. 


\section{Establishment of "online + offline" Blended Teaching System}

The "online + offline" blended teaching pattern has two important links: online learning and offline classroom learning. In the blended teaching pattern, students should first complete the online learning of basic theoretical knowledge, and then class discussion and case teaching were organized by teachers. After class, students communicate with teachers and classmates through online learning platform, so as to realize the internalization and sublimation of knowledge. The whole learning process is divided into three stages: pre-class autonomous online learning, in-class face-to-face teaching and after-class online learning. The students watched the teaching micro video, completed the advanced practice, and made clear the basic target to study autonomously before class. In classroom teaching, in order to targeted guide students, teacher timely grasp the learning foundation and learning perplexity of each student by taking advantage of the opportunities of face-to-face communication between teachers and students. After class, students finish the extended exercise to achieve in-depth study of knowledge. The specific teaching tasks of the three stages is shown in Fig. 1.

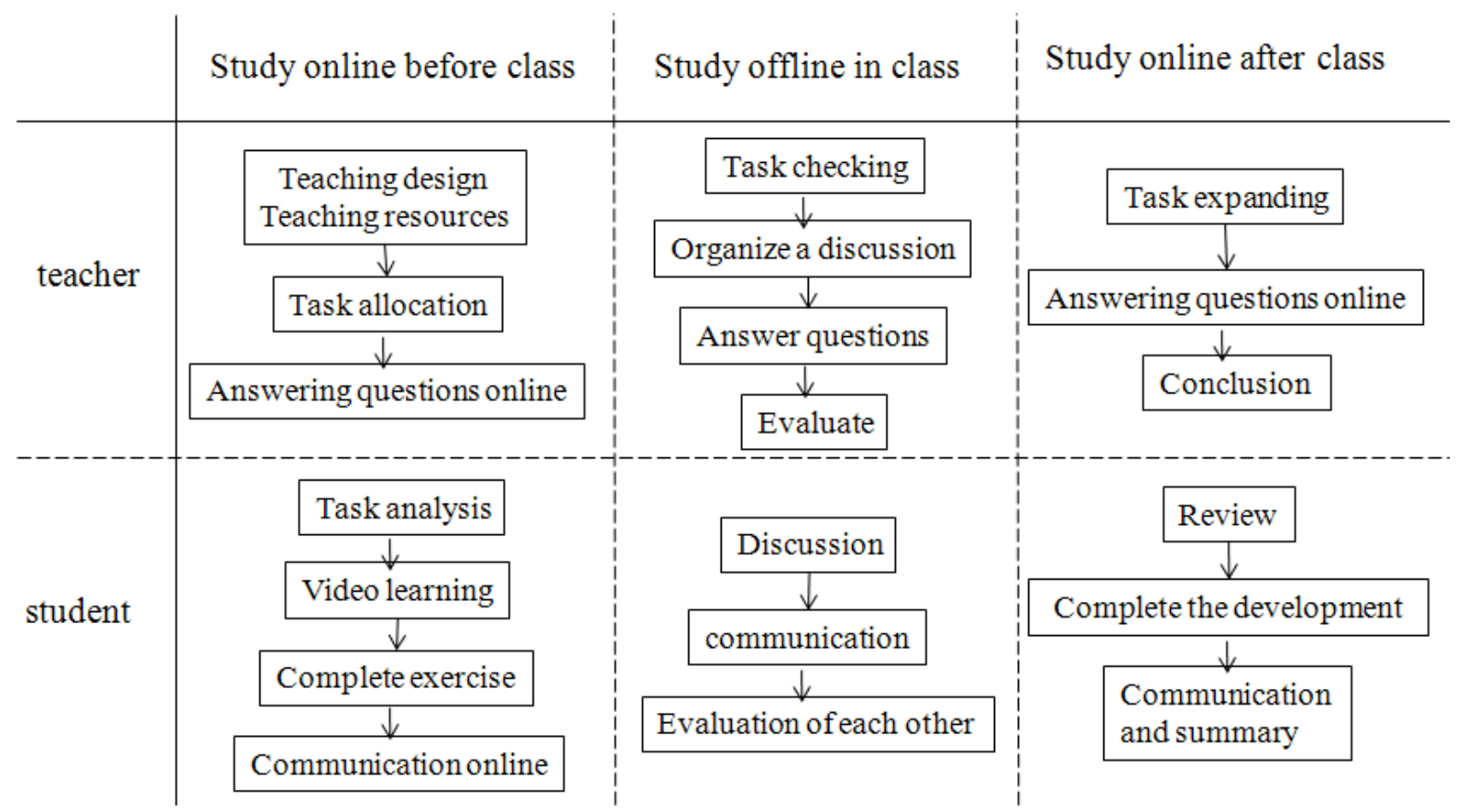

Figure 1. Finite System of "online + offline" blended teaching

\section{Implementation of "online + offline" Blended Teaching}

Study Online before Class. The autonomous learning stage requires learners to complete the independent study of basic knowledge out of class. At this stage, teachers need to carry out detailed teaching design and prepare teaching resources (including teaching courseware, teaching video, practice questions, etc.), and distribute them to students through online teaching platform. Teacher will clarify the learning task of this lesson and assign the task to each study group. The online q\&a session is mainly aimed at online solutions to questions encountered in the learning process of students. Students can also discuss with each other through learning platforms. Before class, students should watch the teaching micro video and complete the advanced practice. For the problems appeared in video learning or practice, students should discuss with each other first and then turn to the teacher for help.

Discuss and Study Offline in Class. At this stage, teachers design corresponding classroom activities, and students have a deeper understanding of knowledge points through mutual discussion and evaluation, and learn the flexible application of knowledge points. First of all, teachers judge the study status of the students by asking questions or the completed exercises before the students' 
class. Secondly, teachers design some difficult problems and confusing concepts, and students will discuss them in groups. And then teachers can focus on problems that students can't understand through discussion. Then, for individual students who have difficulty in learning, teachers can assist or guide them independently according to the specific situation. Finally, teachers summarized the knowledge points of this lesson. Classroom teaching can be conducted in the following forms:

(1) Discussion. It can be discussed in a variety of forms: students ask questions, and then teacher organizes the students to discuss, and finally supplements and summarizes. We can also discuss the various knowledge points, and let the excellent students come to the platform to explain. The discussion can deepen the mastery of knowledge points. The discussion takes about $40-50 \%$ of the total class time.

(2) Question and Answer. For individual students to answer questions, focus on students of different learning abilities, so that students are not left behind too far. The Question and Answer takes about $20-30 \%$ of the total class time.

(3) Experimental teaching. In addition to basic experimental teaching, demonstration experiments in class are carried out in practice. One way to do this is to project the experiment video onto the screen. The EDA software can also be used for classroom simulation demonstration. The simulation software of mutidilm is used to conduct the simulation experiment and the circuit analysis and design. These experiments enable students to feel the visual effects of the experiment in the classroom, stimulate the learning interest and the enthusiasm and creativity of the students. The experimental teaching takes about $20-30 \%$ of the total class time.

Learn Online After Class. After class, teachers sorted out the typical problems in the class, and expanded them according to the actual situation of the groups. Teachers guarantee a fixed period of time online to answer the questions that students may have. Students should sorte out and summarize the main points of this lesson according to the experience of class discussion, and then they should finish the expanded tasks by consulting the data, discussing with each other and other ways. For the unclear part, students can discuss with each other through online learning platform, they can also discuss with teachers more deeply about the content of the class.

\section{Teaching Effect}

In order to verify the effect of "online + offline" blended learning, the author compared the two classes students of electronic information science and technology major. The examination results of the test class students were compared with those of the class students who adopted the traditional teaching methods, and the comparison table was made, as shown in table 1.

The comparison shows that: (1) The average scores, pass rate and the excellent rate in the experimental class were higher than those of the regular class. (2) In the pilot class, the students' scores were mainly between 70 and 90, while the average student in the regular class had a large proportion of 60-80. This indicates that the new teaching mode can promote the study of most students, and the blended teaching pattern is obviously superior to the traditional one in the assessment results.

Table 1 Contrast between traditional and blended learning performance

\begin{tabular}{ccccc}
\hline Teaching mode & $\begin{array}{c}\text { Average } \\
\text { score }\end{array}$ & $\begin{array}{c}\text { Main distribution } \\
\text { interval }\end{array}$ & $\begin{array}{c}\text { Pass } \\
\text { rate }\end{array}$ & $\begin{array}{c}\text { Excellent } \\
\text { rate }\end{array}$ \\
\hline $\begin{array}{c}\text { Traditional } \\
\text { teaching } \\
\begin{array}{c}\text { Blended } \\
\text { teaching }\end{array}\end{array}$ & 67.8 & $60-80(70 \%)$ & $73.3 \%$ & $6.67 \%$ \\
\hline
\end{tabular}




\section{Conclusion}

The circuit principle course adopts the blended teaching pattern of "online + offline", which is conducive to breaking through the limitation of traditional teaching mode. Students can be free to study anytime and anywhere without the restriction of time and space. With the help of mobile Internet, students in private colleges and universities should be able to choose high-quality network teaching resources. Blended teaching can give full play to students' main role, improve students' enthusiasm and initiative, and stimulate their innovative consciousness and innovation ability. Therefore, the problems existing in current course teaching can be solved to some extent.

In teaching practice, we need to carry on continuous reform and exploration, hoping to achieve better teaching effect.

\section{Acknowledgements}

Shaanxi province education science "choices-and graver consequences-in" planning project (SGH17H475);

The research project on the transformation of online curriculum in 2017 at the higher education MOOC center in shaanxi province (17MZ56).

\section{References}

[1] J.J. Tian: Education Teaching Forum, (2017) No.39 , p.179.( In Chinese)

[2] Q.J. Song, P. Wu and L. Yin: Higher Education Forum, (2016) No.3, p. 48. ( In Chinese)

[3] K.K. He: E-Education Research, (2004) No.3, p. 1. ( In Chinese)

[4] H. Singh. C. Reed: A White Paper: Achieving Success with Blended Learning [DB/OL]. http: // www. leerbeleving. nl/ wbts / wbt2014 / blend-ce.pdf . 2001.

[5] J.H. Gao, J. Zhu: Modern Educational Technology, (2015) No.1, p. 32. ( In Chinese)

[6] J.Y. Li, Y.M. Li: Journal of Beijing City University, (2016) No.134, p. 13. ( In Chinese)

[7] H. Li, K. Zheng: Computer Era, (2017)No.2 , p. 65. ( In Chinese)

[8] J.T. Wang, M. Zhang and Z.H. Wang: Microcomputer Applications, Vol.33(2017) No.9 , p.15.

[9] H. Xue: Microcomputer Applications, Vol.33 (2017) No.3, p.42. (In Chinese)

[10]L.X. Xie: Education Teaching Forum, (2017) No.20 , p.169. ( In Chinese) 